\title{
Removal of hydrogen sulfide by physico-biological filter using mixed rice husk silica and dried activated sludge.
}

\begin{abstract}
This study investigated the effectiveness of a new packing material, namely mixed rice husk silica with dried activated sludge for removing H2S. Dried sewage sludge was collected from Putrajaya sewage treatment plant in Malaysia. Rice husk silica was prepared at temperature of $800^{\circ} \mathrm{C}$, after acid leaching and mixed with dried sewage sludge to be utilized in a polyvinyl chloride filter. The system was operated under variable conditions of two parameters, different inlet gas concentration and different inlet flow rate. H2S was passed through the filter with one liter of the packing material. More than $99.96 \%$ removal efficiency (RE) with empty bed residence time (EBRT) of 90-45 s and 300 ppm inlet concentration was observed. However, the RE decreased to $96.87 \%$ with the EBRT of $30 \mathrm{~s}$. The maximum elimination capacity (EC) of $52.32 \mathrm{~g} / \mathrm{m} 3 / \mathrm{h}$ was obtained with the RE of $96.87 \%$ and $\mathrm{H} 2 \mathrm{~S}$ mass loading rate of $54 \mathrm{~g} / \mathrm{m} 3 / \mathrm{h}$, while at the RE of $99.96 \%$, maximum EC was $26.99 \mathrm{~g} / \mathrm{m} 3 / \mathrm{h}$ with the $\mathrm{H} 2 \mathrm{~S}$ mass-loading rate of $27 \mathrm{~g} / \mathrm{m} 3 / \mathrm{h}$. A strong significant correlation between increasing of $\mathrm{H} 2 \mathrm{~S}$ mass loading rate and pressure drop was also detected $(\mathrm{p}<0.01)$. Maximum pressure drop was $3.0 \mathrm{~mm} \mathrm{H} 2 \mathrm{O}$ after 53 days of operating time, the EBRT of $30 \mathrm{~s}$, and $54 \mathrm{~g} / \mathrm{m} 3 / \mathrm{h}$ of $\mathrm{H} 2 \mathrm{~S}$ loading rate. These observations suggest that the mixture of rice husk silica with dried activated sludge is a suitable physico-biological filter for $\mathrm{H} 2 \mathrm{~S}$ removal.
\end{abstract}

Keyword: Air pollution; Elimination capacity; Empty bed residence time; Packing material; Removal efficiency. 